\title{
Panmictic population structure in the migratory marine sparid Acanthopagrus australis despite its close association with estuaries
}

\author{
David G. Roberts*, David J. Ayre \\ Institute for Conservation Biology and Environmental Management, School of Biological Sciences, \\ University of Wollongong, Wollongong, New South Wales 2522, Australia
}

\begin{abstract}
Recent studies have revealed surprising levels of genetic structuring within populations of marine species that were previously thought to be widely dispersed. Such subdivision may reflect unexpected physical or biological barriers to dispersal, including philopatric behaviour. Here we investigate the genetic structure of the eastern Australian yellowfin bream Acanthopagrus australis - a widely distributed species that is thought to be highly dispersive but is also known to spawn in close association with estuaries. Our data from surveys of allele frequencies at 6 microsatellite DNA loci for 350 fish revealed high levels of genetic diversity within all sites but no genetic differentiation of groups of recruits collected from sites separated by a distance of up to $50 \mathrm{~km}$ (allele frequency differentiation: $F_{\mathrm{ST}}=0.002, \mathrm{p}>0.05$ ). Moreover, there was no differentiation of adults spread across the distributional range of the species (several 100s of kilometers, $F_{\mathrm{ST}}=0.002$ ). We conclude that $A$. australis spawning is opportunistically associated with estuaries in general, and that the species essentially forms a panmictic population with a genetic homogeneity reflecting the predicted active northwards dispersal of adults and the southwards dispersal of larvae as affected by the Eastern Australian Current.
\end{abstract}

KEY WORDS: Dispersal · Gene flow $\cdot$ East Australian Current $\cdot$ Microsatellites $\cdot$ Sparidae $\cdot$ Coastal lake or lagoon · Yellowfin bream

\section{INTRODUCTION}

Mobile marine organisms such as fish may be expected to form large populations that are strongly interconnected by dispersal, and hence display little genetic subdivision. However, recent studies have highlighted both the surprisingly restricted dispersal of many marine taxa (Jones et al. 1999, Almany et al. 2007) and the consequent high level of population subdivision even within taxa with long-lived larvae or mobile adults (Ayre \& Dufty 1994). Many factors, including ocean currents (James et al. 2002), coastal features such as estuaries or embayments (Watts \& Johnson 2004), and complex larval and/or adult behaviour (Gerlach et al. 2007, Dixson et al. 2008), have been implicated. Hence, predictions that the life history of fish should result in widespread dispersal must always be treated with caution.

A diverse range of marine animals displays spawning site fidelity (e.g. sea kraits, Shetty \& Shine 2002; turtles, Bowen et al. 2005, groupers, Starr et al. 2007). This trait is common in many groups of fish and may involve the adults returning to their place of birth to spawn (i.e. natal-site spawning) (e.g. Thorrold et al. 2001). Although the exact mechanism facilitating spawning site faithfulness is often unclear, it seems probable that it relies on individuals sensing and 'homing' to some underlying characteristic or environmental factor associated with the spawning site. For example, the navigational mechanism facilitating natal-site spawning in estuarine (i.e. stream or river) dependent salmon is thought to involve olfactory imprinting (dur- 
ing early life stages), and subsequent sensing of natalsite odours (Dittman \& Quinn 1996, Yamamoto et al. 2010).

On the east coast of Australia, Acanthopagrus australis Günther (yellowfin bream) is considered to be highly mobile and is treated as a single (fisheries) stock ranging over $>2000 \mathrm{~km}$ from southern Queensland (QLD) to the New South Wales (NSW)/Victoria (VIC) state border (Henry \& Lyle 2003). Indeed, 2 studies have shown bream (which the authors assumed were A. australis rather than the estuary restricted congener A. butcheri Munro (black bream) that were tagged within both central and northern NSW estuaries being recaptured in locations in southern Queensland (Henry 1983, West 1993). While these tagging studies clearly show that a small proportion of $A$. australis undertake long-distance migration (in a southerly direction, ranging over 10 s to 100 s of kilometres) (proportion of the total no. of fish that emigrated to the total no. of fish tagged and released: 29/589, 12588 [total no. of fish tagged], West 1993; 4/88, 1058 [total no. of fish tagged], Henry 1983), both authors reported that the majority of recaptured fish were caught within the estuary in which they were tagged (560/589 and 84/88 respectively). These findings support earlier work by Pollock (1982a), who similarly used capturetag-release-recapture data to show that $A$. australis inhabiting Moreton Bay (QLD) at approximately the northern range limit of the species should be considered as a separate (fisheries) stock, as fish did not emigrate outside of Moreton Bay. Taken at face value, these findings, together with aspects of the life history of $A$. australis, suggest that populations could be genetically subdivided.

Although adult Acanthopagrus australis are thought to migrate in a southerly direction to spawn, and pelagic larvae are thought to be dispersed over large distances by the East Australian Current (EAC), the species may display spawning site fidelity. Spawning behaviour is relatively unstudied in A. australis, although spawning is thought to occur in entrance channels or lower reaches of coastal lakes and lagoons ('estuaries') or in the surf zone of beaches adjacent to the entrances of estuaries (Pollock 1982b, 1984). This close association with estuarine spawning sites has the potential to promote fine-scale genetic differentiation of both adult and juvenile popu- lations if $A$. australis lineages maintain prolonged associations with individual estuaries. Alternatively, if spawning is simply opportunistically associated with estuaries in general, and larvae are mixed and transported over a wide area by the EAC, then we would expect little or no population subdivision.

Here we use population genetic data to test the prediction that spawning site fidelity promotes fine-scale population subdivision in Acanthopagrus australis. Specifically, we compare the degree of genetic differentiation of sets of $A$. australis recruits within different estuaries with that of adults caught near estuaries but on the open coast.

\section{MATERIALS AND METHODS}

The Acanthopagrus species complex, sample collections, and genetic markers. A. australis is distributed continuously along the east coast of Australia from southern QLD to approximately the NSW/VIC state border (Fig. 1) (Edgar 2000). It inhabits a range of habitats encompassing rocky headlands, offshore reefs and the surf zone of coastal beaches as well as estuaries. The species has an annual reproductive cycle, with asynchronous gonad development and group spawning occurring over a period of 2 to 5 mo. Peak spawning occurs between April and June (on

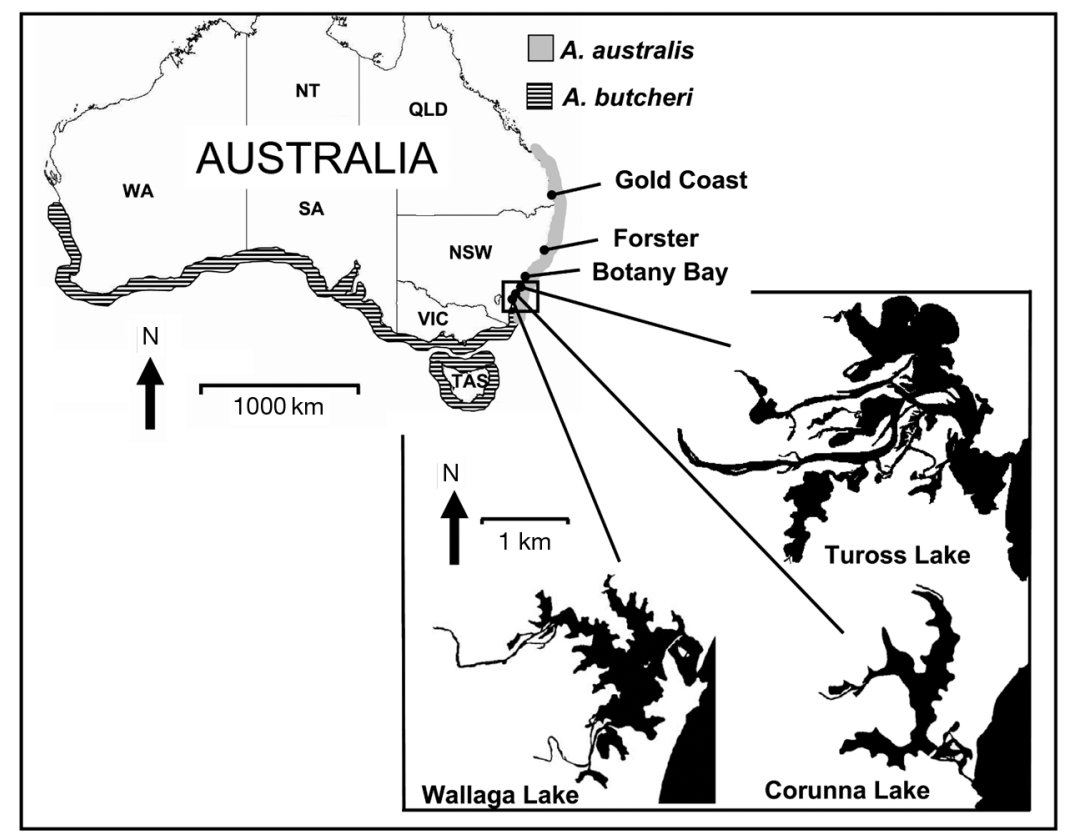

Fig. 1. Distribution of Acanthopagrus australis and its estuary restricted congener A. butcheri, and the locations of sampling sites for juvenile (Tuross, Corunna and Wallaga Lakes) and adult (Gold Coast, Forster and Botany Bay) A. australis 
the north coast but may be later on the south coast, i.e. July/August, C. A. Gray pers. comm.). During the spawning period, an unknown proportion of the population is thought to migrate in a southerly direction along the coast, with fish forming large aggregations in the lower reaches of estuaries and/or in the immediate surf zone of coastal beaches directly adjacent to the entrances of estuaries, presumably to spawn (Pollock 1982b, 1984). Larvae may be dispersed over a wide area as they are thought to spend a large amount of time in the coastal ocean plankton under the influence of the East Australian Current (EAC) while undergoing development (Neira et al. 1998) before recruiting to shallow seagrass meadows and submerged structures in coastal lakes and lagoons (Griffiths 2001).

The dispersal potential of Acanthopagrus australis could have serious implications for its estuary restricted congener, A. butcheri. This is because on the southeast corner of Australia where the 2 species co-occur within estuaries, A. australis has made a major contribution to the genotypes of $A$. butcheri through hybridisation and introgression (Rowland 1984, Roberts et al. 2009). The juvenile A. australis examined in this study represent a subset of a collection of Acanthopagrus spp. from Roberts et al. (2010), who determined the proportion of A. australis, A. butcheri and introgressed or hybrid bream within 5 coastal lagoons in southern NSW. Roberts et al. (2010) collected 688 juvenile (<30 mm length) Acanthopagrus spp. (81 to 170 per lagoon) following a single recruitment event in 2002, after the 2001 spawning. Between 20 and 66 bream were sampled at each of 3 or 4 haphazardly chosen sites (within seagrass meadows) in each lagoon. Bream were captured with a $10 \times$ $2 \mathrm{~m}$ haul seine net (6 mm mesh) over a $\sim 25 \mathrm{~m}^{2}$ area. The species specific status of every individual was determined using admixture analysis based on 8 microsatellite loci, and a species specific mtDNA RFLP (restriction fragment length polymorphism) profile (Roberts et al. 2010). The microsatellite markers and the PCR cycling conditions are described in Roberts et al. (2009).

We examined microsatellite genotypes for 30 randomly selected juvenile Acanthopagrus australis from 2 or 3 sites, within each of 3 lagoons on the NSW south coast (Tuross, Corunna and Wallaga Lakes) separated by a distance of up to $50 \mathrm{~km}$ (total $\mathrm{n}=240 \mathrm{fish}$ ). We also genotyped sets of ocean-caught adults from each of 3 locations: the Gold Coast (QLD) ( $\mathrm{n}=40)$, Forster ( $\mathrm{n}=$ 40 ) and Botany Bay $(\mathrm{n}=30)(\mathrm{NSW})$ (total $\mathrm{n}=110$ ) (Fig. 1). These fish were included to compare the genetic similarity of juvenile bream on the south coast of NSW to adult bream from throughout the described range of the species.
Genetic analyses: microsatellites. For each site within a lagoon, and for each ocean location, we calculated the average number of alleles per locus, and the average observed and expected heterozygosity (using POPGENE; Yeh et al. 1999).

Because incorrect interpretation of microsatellite data can occur when there are genotyping errors associated with null alleles, stutter bands due to replication slippage during PCR, and/or large allele dropout, we determined whether our data were affected by these potential sources of error using the program Micro Checker (van Oosterhout et al. 2004). Separate analyses on the overall collection of juveniles and adults for each lagoon and ocean site revealed that 2 loci ( $p A b 2 A 5$ and $A c s 3^{*}$ ) had apparent large excesses of homozygotes consistent with null alleles. Although a small number of controlled crosses involving Acanthopagrus butcheri $\times A$. butcheri, and A. australis $\times A$. butcheri have revealed simple Mendelian inheritance and no evidence of null alleles for the 8 microsatellite loci (4 pairs; 30 larvae per pair) (Roberts et al. 2009), we have opted to present the results here based on just 6 loci, acknowledging the possibility of null alleles at $p A b 2 A 5$ and $A c s 3^{*}$ in A. australis.

We estimated Weir \& Cockerham's (1984) formulations of Wright's (1969) F-statistics using the program Tools for Population Genetic Analyses (TFPGA; Miller 1997). Our hierarchical sampling of juveniles within south coast lagoons allowed us to partition genetic variation into separate variance components. In the present study, the hierarchical levels in the data were denoted by $F_{\mathrm{SL}}$ and $F_{\mathrm{LT}}$, which respectively represent genetic differentiation among sites within a specified lagoon, and among lagoons relative to the total. $F_{\text {IS }}$ and $F_{\text {IT }}$ are measures of the deviation from Hardy-Weinberg expectations within subpopulations (i.e. lagoons) and in the total population (sample) respectively, and are presented in the conventional way. The estimates were based on microsatellite allele frequencies for individual loci, and as an average across loci. Bootstrapping and jackknifing over loci were used to estimate SDs and $95 \%$ CIs. F-statistics were considered statistically significant when the lower $95 \% \mathrm{CI}$ did not overlap 0. Comparable F-statistics for ocean-caught adults were also included, although our sampling did not permit a hierarchical assessment of population differentiation. We tested for differentiation of adult and juvenile Acanthopagrus australis by calculating $F_{\mathrm{ST}}$ (i.e. allele frequency differentiation among subpopulations) for the overall sets of adult and juvenile fish. Finally, to visually display any geographic structuring within our microsatellite data set, we performed factorial correspondence analysis (FCA) in GENETIX 4.03 (Belkhir et al. 2002) on the pooled sample of juveniles from each lagoon together with the sample of ocean-caught adults. 
Table 1. Acanthopagrus australis. Mean $( \pm \mathrm{SE})$ number of alleles $(A)$, number of private alleles (alleles unique to a particular site) $\left(A_{\mathrm{P}}\right)$, observed heterozygosity $\left(H_{\mathrm{o}}\right)$, Nei's 1973 expected heterozygosity $\left(H_{\mathrm{e}}\right)$, and the estimator $f$ of the inbreeding coefficient, $F_{\mathrm{IS}}$ (Weir \& Cockerham 1984) based on 6 microsatellite loci, for juveniles (representing the same year of birth) in 3 coastal lagoons in southeastern Australia. Sample size was 30 fish per site. ${ }^{*}$ Statistically significant departure from Hardy-Weinberg equilibria, $\mathrm{p}<0.05$

\begin{tabular}{|c|c|c|c|c|c|c|c|c|}
\hline & \multicolumn{3}{|c|}{ Tuross } & \multicolumn{3}{|c|}{ Corunna } & \multicolumn{2}{|c|}{ Wallaga } \\
\hline & Site 1 & Site 2 & Site 3 & Site 1 & Site 2 & Site 3 & Site 1 & Site 2 \\
\hline A & $\begin{array}{l}11.3 \\
(1.9)\end{array}$ & $\begin{array}{l}11.8 \\
(2.1)\end{array}$ & $\begin{array}{l}11.5 \\
(2.6)\end{array}$ & $\begin{array}{l}11.8 \\
(2.3)\end{array}$ & $\begin{array}{l}11.7 \\
(2.0)\end{array}$ & $\begin{array}{l}11.3 \\
(1.7)\end{array}$ & $\begin{array}{l}11.7 \\
(2.2)\end{array}$ & $\begin{array}{l}13.0 \\
(1.8)\end{array}$ \\
\hline$A_{\mathrm{P}}$ & $\begin{array}{c}0.33 \\
(0.21)\end{array}$ & $\begin{array}{c}0.50 \\
(0.22)\end{array}$ & $\begin{array}{c}0.00 \\
(0.00)\end{array}$ & $\begin{array}{c}0.17 \\
(0.17)\end{array}$ & $\begin{array}{c}0.50 \\
(0.22)\end{array}$ & $\begin{array}{c}0.50 \\
(0.22)\end{array}$ & $\begin{array}{c}0.00 \\
(0.00)\end{array}$ & $\begin{array}{c}0.67 \\
(0.21)\end{array}$ \\
\hline$H_{\mathrm{o}}$ & $\begin{array}{c}0.833 \\
(0.092)\end{array}$ & $\begin{array}{c}0.788 \\
(0.107)\end{array}$ & $\begin{array}{c}0.806 \\
(0.184)\end{array}$ & $\begin{array}{c}0.778 \\
(0.136)\end{array}$ & $\begin{array}{c}0.759 \\
(0.090)\end{array}$ & $\begin{array}{c}0.817 \\
(0.089)\end{array}$ & $\begin{array}{c}0.811 \\
(0.103)\end{array}$ & $\begin{array}{c}0.783 \\
(0.161)\end{array}$ \\
\hline$H_{\mathrm{e}}$ & $\begin{array}{c}0.813 \\
(0.083)\end{array}$ & $\begin{array}{c}0.790 \\
(0.104)\end{array}$ & $\begin{array}{c}0.783 \\
(0.133)\end{array}$ & $\begin{array}{c}0.790 \\
(0.123)\end{array}$ & $\begin{array}{c}0.801 \\
(0.106)\end{array}$ & $\begin{array}{c}0.812 \\
(0.099)\end{array}$ & $\begin{array}{c}0.796 \\
(0.112)\end{array}$ & $\begin{array}{c}0.807 \\
(0.120)\end{array}$ \\
\hline$f$ & -0.009 & 0.020 & -0.011 & 0.031 & $0.076^{*}$ & 0.011 & -0.002 & $0.047^{*}$ \\
\hline
\end{tabular}

Table 2. Acanthopagrus australis. Hierarchical F-statistics estimated for 6 microsatellite loci, and overall, for juveniles within 3 coastal lagoons. $F_{\mathrm{SL}}$ and $F_{\mathrm{LT}}$ : genetic differentiation among sites within lagoons, and among lagoons respectively. $F_{\mathrm{IS}}$ and $F_{\mathrm{IT}}$ : degree of deviation from Hardy-Weinberg expectations within lagoons and within the total sample. F-statistics were considered statistically significant when the lower $95 \%$ CI did not overlap 0

\begin{tabular}{|lcccc|}
\hline Locus & $F_{\mathrm{IS}}$ & $F_{\mathrm{SL}}$ & $F_{\mathrm{LT}}$ & $F_{\mathrm{IT}}$ \\
\hline$p A b 2 B 7$ & 0.045 & 0.004 & 0.003 & 0.049 \\
$p A b 2 D 1$ & -0.020 & 0.002 & -0.002 & -0.018 \\
$A c s 1^{*}$ & 0.031 & 0.006 & 0.011 & 0.037 \\
$A c s 6^{*}$ & 0.033 & -0.005 & 0.004 & 0.028 \\
$A c s-16^{*}$ & 0.014 & 0.001 & -0.001 & 0.015 \\
$A c s-21^{*}$ & 0.013 & -0.001 & -0.004 & 0.012 \\
Overall $\pm \mathrm{SD}$ & $0.021 \pm 0.008$ & $0.001 \pm 0.002$ & $0.002 \pm 0.002$ & $0.022 \pm 0.009$ \\
$95 \% \mathrm{CI}$ & $0.004-0.008$ & $-0.001-0.004$ & $-0.002-0.006$ & $0.004-0.037$ \\
\hline
\end{tabular}

no genetic subdivision at either spatial scale. Our estimates of $F_{\text {IS }}$ and $F_{\text {IT }}$ were also consistently close to 0 $(0.021 \pm 0.008$ and $0.022 \pm 0.009$ respectively), which together with the lack of spatial variation in allele frequencies, imply a single outcrossed population (Table 2).

Genetic diversity in ocean-caught adults on the north coast was comparable to levels of genetic diversity in the set of juveniles within lagoons on the south coast. The mean number of alleles per locus ranged between 11.5 and 12.2, while mean observed heterozygosity was similarly $\geq 0.75$ for each location (Table 3).

\section{RESULTS}

The overall collection of juvenile Acanthopagrus australis comprised a genetically diverse group with little evidence of genetic subdivision. Numbers of alleles per locus ranged between 9 and 30 , with an average ( \pm SE) of $17.7( \pm 3.0)$. We detected similar levels of genetic variation at all sites within each lagoon. The mean number of alleles per locus ranged between 11.3 and 13.0, while mean observed heterozygosity was $>0.75$ for each site (range: $0.76-0.83$ ). Between 64.2 and $73.6 \%$ of all alleles were present at each site. Private alleles (alleles unique to a single site) were extremely rare $(16 / 106$ alleles detected), and were found at low frequency $(<0.05)$ when they occurred. Private alleles were distributed evenly among sites within lagoons (Table 1).

Our estimates of genetic variation among sites within lagoons $\left(F_{\mathrm{SL}}: 0.001 \pm 0.002\right)$ and among lagoons $\left(F_{\mathrm{LT}}: 0.002 \pm 0.002\right)$ were extremely low and not significantly different from 0 (based on $95 \%$ CIs), indicating
There was no population differentiation among samples of ocean-caught Acanthopagrus australis from locations that were spread across the described range of the species $\left(F_{\mathrm{ST}}=0.002 \pm 0.001 ; 95 \% \mathrm{CI}=\right.$ 0.000-0.004) (Table 4). Perhaps not surprisingly, the FCA plot that was used to compare the genetic simila-

Table 3. Acanthopagrus australis. Mean $( \pm \mathrm{SE})$ number of alleles $(A)$, number of private alleles (alleles unique to a particular location) $\left(A_{\mathrm{P}}\right)$, observed heterozygosity $\left(H_{\mathrm{o}}\right)$ and Nei's 1973 expected heterozygosity $\left(H_{\mathrm{e}}\right)$ based on 6 microsatellite loci, for ocean-caught adults. Sample size per location was 40, 40 and 30 fish, respectively

\begin{tabular}{|lccc|}
\hline & Gold Coast & Forster & Botany Bay \\
\hline$A$ & $12.2(2.1)$ & $12.0(2.6)$ & $11.5(2.7)$ \\
$A_{\mathrm{P}}$ & $1.5(0.3)$ & $1.5(0.7)$ & $1.0(0.4)$ \\
$H_{\mathrm{o}}$ & $0.748(0.061)$ & $0.771(0.037)$ & $0.787(0.051)$ \\
$H_{\mathrm{e}}$ & $0.800(0.048)$ & $0.789(0.054)$ & $0.800(0.048)$ \\
\hline
\end{tabular}


Table 4. Acanthopagrus australis. F-statistics estimated for 6 microsatellite loci, and overall, for ocean-caught adults, and for the pooled set of juvenile (estuarine) and adult fish. $F_{\mathrm{IS}}$ and $F_{\mathrm{IT}}$ : degree of deviation from Hardy-Weinberg expectations within lagoons and within the total sample; $F_{\mathrm{ST}}$ : allele frequency differentiation among subpopulations (i.e. sampling locations)

\begin{tabular}{|c|c|c|c|c|c|c|}
\hline \multirow{2}{*}{ Locus } & \multicolumn{3}{|c|}{ Adult } & \multicolumn{3}{|c|}{ Adult \& juvenile } \\
\hline & $F_{\mathrm{IS}}$ & $F_{\mathrm{ST}}$ & $F_{\mathrm{IT}}$ & $F_{\mathrm{IS}}$ & $F_{\mathrm{ST}}$ & $F_{\mathrm{IT}}$ \\
\hline$p A b 2 B 7$ & 0.085 & -0.005 & 0.085 & 0.059 & -0.001 & 0.059 \\
\hline$p A b 2 D 1$ & 0.034 & 0.005 & 0.039 & -0.001 & 0.001 & -0.001 \\
\hline$A c s 1^{*}$ & 0.059 & 0.000 & 0.059 & 0.041 & -0.003 & 0.039 \\
\hline$A c s 6^{*}$ & 0.034 & 0.005 & 0.039 & 0.031 & -0.001 & 0.030 \\
\hline$A C S-16^{*}$ & 0.035 & 0.001 & 0.036 & 0.021 & 0.001 & 0.022 \\
\hline ACS $-21^{*}$ & 0.024 & 0.001 & 0.026 & 0.017 & -0.001 & 0.016 \\
\hline Overall $\pm \mathrm{SD}$ & $0.046 \pm 0.010$ & $0.002 \pm 0.001$ & $0.047 \pm 0.010$ & $0.029 \pm 0.008$ & $-0.001 \pm 0.001$ & $0.029 \pm 0.008$ \\
\hline $95 \% \mathrm{CI}$ & $0.031-0.066$ & $0.000-0.004$ & $0.033-0.066$ & $0.015-0.045$ & $-0.002-0.001$ & $0.015-0.044$ \\
\hline
\end{tabular}

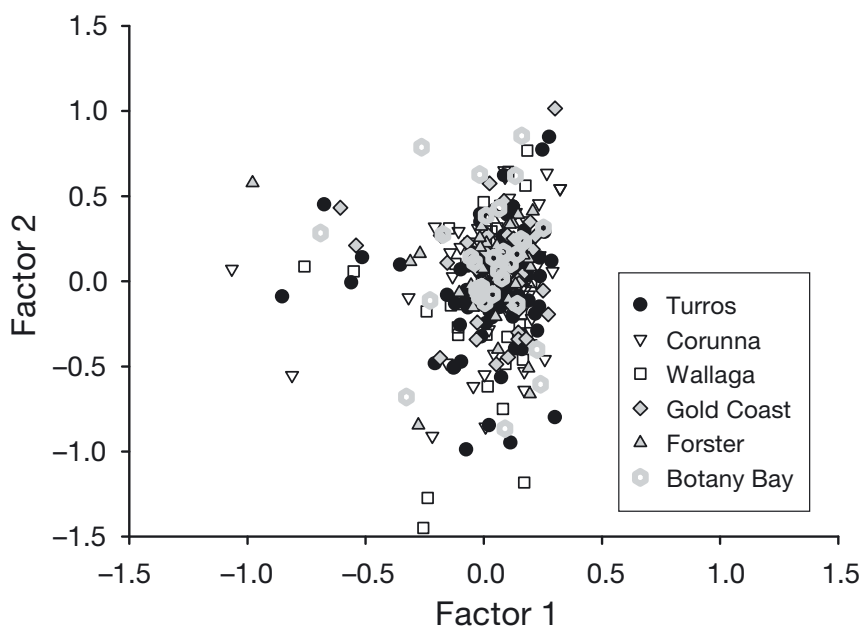

Fig. 2. Acanthopagrus australis. Factorial correspondence analysis based on the 6 locus genotype of all 350 fish. $\mathrm{n}_{\text {juveniles }}=240$ (Tuross, Corunna and Wallaga); $\mathrm{n}_{\text {adults }}=110$ (Gold Coast, Forster and Botany Bay). Juveniles were caught within coastal lagoons, while adults represent ocean-caught fish

rity of individual juveniles within lagoons on the south coast to that of ocean-caught adults on the north coast revealed a wide scatter of points along both axes but with the plotted positions of points for the juveniles and adults overlapping (Fig. 2). No sets of juveniles or adults formed clusters of individuals from the same sampling location. Moreover, $F_{\mathrm{ST}}$ based on comparison of the overall data set of adult and juvenile fish revealed no genetic differentiation $\left(F_{\mathrm{ST}}=0.000\right)$ (Table 4$)$.

\section{DISCUSSION}

Our findings suggest that Acanthopagrus australis forms a genetically diverse and homogeneous population despite the potential for population subdivision suggested by its close association with estuaries. These results are consistent with the great mobility of this species that has been predicted from tagging studies (Henry 1983, West 1993), and imply that fish have no persistent associations with their natal spawning sites or nursery estuaries. Indeed, all estuarine populations were genotypically diverse and genetically homogenous over spatial scales ranging from several hundreds of meters to tens of kilometres. Estuaries can provide unique opportunities for divergence (see Watts \& Johnson 2004 for review), and there are examples where species of fish that are otherwise 'good dispersers' (i.e. mobile adults, with dispersive pelagic larvae) exist as estuary associated, genetically subdivided populations (Johnson et al. 1986, Gold et al. 1999). Our data show that dispersal is clearly sufficient to prevent geographic differentiation of $A$. australis populations despite the acknowledged association of adult $A$. australis with estuaries as feeding and spawning sites. However, this need not imply vast amounts of migration, but simply enough migration to homogenise allele frequencies (Wright 1931). The lack of genetic heterogeneity in $A$. australis among estuaries sharply contrasts with the pattern of genetic subdivision that has been reported for its estuary restricted congener, $A$. butcheri, in at least some parts of its range (Chaplin et al. 1998).

The complete lack of spatial variation in allele frequencies for collections of ocean-caught adult and juvenile Acanthopagrus australis from several estuaries suggests that this species effectively forms a single large panmictic population on Australia's east coast. Our data for ocean-caught adults alone could reflect the post-spawning migration and possible mixing of adults from genetically distinct estuary associated subpopulations (i.e. marine admixture). Species that display strong philopatry and consequent genetic subdivision of spawning aggregations often forage or migrate over vast distances before returning to natal 
sites to spawn (e.g. Bowen et al. 2005). Thus, the limitation of our data set based on ocean-caught adults alone is that we are unable to distinguish between rangewide genetic homogeneity and marine admixture of a set of genetically distinct estuary associated subpopulations. However, the genetic homogeneity of juveniles provides more compelling evidence of the lack of any persistent genetic subdivision of populations that is attributable to an association with estuaries.

Our data are consistent with what is known of the breeding biology of Acanthopagrus australis and east coast oceanography, and suggest that both the southerly migration of adults and northerly dispersal of larvae via the EAC provide sufficient mixing to prevent rangewide population differentiation. The EAC is the major ocean current on the east coast. It produces a reliable, predominantly north-south flow of warm water originating in the tropics, but becomes progressively weaker and less reliable from $\sim 33^{\circ} \mathrm{S}$ (central NSW), as the majority of the flow is deflected seaward in this area (Godfrey et al. 1980). Several authors have speculated on the EAC's effectiveness in transporting larvae to the far south coast of eastern Australia (Ayre 1990, Murray-Jones \& Ayre 1997); however, genetic analysis of population differentiation has often revealed genetic homogeneity for widely separated collections of species with longlived pelagic larvae. These include several species that are relatively immobile as adults because of habitat specialisation or attachment to, or within, benthic substrata (Banks et al. 2007, Curley \& Gillings 2009). This homogeneity is most simply explained by a high degree of population connectivity that is maintained by dispersal of larvae within warm-core eddies of the EAC. Although the flow of the EAC is deflected seaward, eddies break off and continue to flow southwards, sometimes reaching the Bass Straight between Tasmania and the Australian mainland $\left(40^{\circ} \mathrm{S}\right)$ (Nilsson \& Cresswell 1981). The physical properties and southward penetration of these eddies vary greatly in space and time (Roughan \& Middleton 2004), and have important implications for the growth, survival and transport of larvae. However, a recent survey of the frequency of occurrence and abundance of tropical (coral) reef fish in temperate subtidal rocky reef habitats in southern NSW highlighted the effectiveness of the warm-core eddies in affecting larval transport (Booth et al. 2007). The authors reported recurring recruitment of a diverse set of reef fish along the NSW coast, remarkably including recruitment at locations near the NSW/VIC state border $\left(38^{\circ} \mathrm{S}\right)$, which is $\sim 1700 \mathrm{~km}$ from the typical southern range limit of these fish on the Great Barrier Reef.

\section{Evolutionary consequences of predicted change to the circulation pattern of the EAC}

Eastern Australia is predicted to experience severe modification of major current flows due to climate change. Indeed, there are already reports of urchins (Centrostephanus rodgersii) being transported to the far south of their previous distributional range limit by the movement of larvae within warm-core eddies of the EAC (Banks et al. 2010), with adult populations now being established in Tasmania and having devastating effects on subtidal kelp forests and associated fauna (Johnson et al. 2005). For Acanthopagrus australis, range expansion may have little direct impact on its population structure, but could have serious implications for its estuary restricted congener, A. butcheri. A. butcheri is distributed within estuaries from southern NSW to Tasmania in the south, and Western Australia in the west. Our earlier works suggested that hybridisation and introgression involving $A$. australis have made a massive contribution to the genotypes of A. butcheri within NSW estuaries (Roberts et al. 2009, Roberts et al. 2010). A northerly range expansion by $A$. australis, facilitated by more frequent or further than usual northerly penetration of warm-core eddies could simply increase the size of this panmictic east coast population. Alternatively, the spread of A. australis may increase both the geographic range within which hybridisation occurs, and the number of hybriddominated lakes and lagoons. Indeed, our preliminary broad-scale genetic survey based on a small number of samples has already uncovered rare hybrids in Tasmanian estuaries (Roberts et al. 2009). Frequent easterly dispersal seems less likely for $A$. australis (although this is not impossible), as we now know that the 'southeast corner' of Australia is a major biogeographic barrier for several species that are regarded as 'good dispersers' (Waters et al. 2007, Ayre et al. 2009). The SE barrier region corresponds to a convergence zone of northerly flowing warm-core eddies of the EAC and cold waters of the westerly flowing Bass Straight Cascade. It therefore represents an area of extreme spatial variation in water temperature and salinity (images can be found at www.bom.gov.au) that presumably blocks along-shore dispersal of adults or transport of larvae. It now seems crucial to employ further genetic surveys of Acanthopagrus spp., beyond the recognised southern and western range limit of $A$. australis to determine baseline proportions of $A$. australis and/or their hybrids.

Acknowledgements. We thank the New South Wales Department of Primary Industries for collection permits; the Australian Research Council linkage and NSW Recreational Fishing Trust for grants to D.J.A., R. J. West and C. A. Gray; the 
Institute for Conservation Biology of the University of Wollongong; R. J. West and C. A. Gray for advice and critical comments; and C. A. Gray and L. Bennet for provision of samples of juvenile fish. This is contribution 297 of the Ecological Genetics Group at the University of Wollongong.

\section{LITERATURE CITED}

Almany GR, Berumen ML, Thorrold SR, Planes S, Jones GP (2007) Local replenishment of coral reef fish populations in a marine reserve. Science 316:742-744

Ayre DJ (1990) Population subdivision in Australian temperate marine invertebrates: larval connections versus historical factors. Austral Ecol 15:403-411

> Ayre DJ, Dufty S (1994) Evidence for restricted gene flow in the viviparous coral Seriatopora hystrix on Australia's Great Barrier Reef. Evolution 48:1183-1201

Ayre DJ, Minchinton TE, Perrin C (2009) Does life history predict past and current connectivity for rocky intertidal invertebrates across a marine biogeographic barrier? Mol Ecol 18:1887-1903

Banks SC, Piggott MP, Williamson JE, Bove U, Holbrook NJ, Beheregaray LB (2007) Oceanic variability and coastal topography shape genetic structure in a long-dispersing sea urchin. Ecology 88:3055-3064

Banks SC, Ling SD, Johnson CR, Piggott MP, Williamson JE, Beheregaray LB (2010) Genetic structure of a recent climate-driven range extension. Mol Ecol 19:2011-2024

Belkhir K, Borsa P, Chikhi L, Raufaste N, Bonhomme F (2002) GENETIX 4.03, logiciel sous Windows ${ }^{\mathrm{TM}}$ pour la génétique des populations. Laboratoire Génome, Populations, Interactions: CNRS UMR:5000. Université Montpellier 2, Montpellier

Booth DJ, Figueira WF, Gregson MA, Brown L, Beretta G (2007) Occurrence of tropical fishes in temperate southeastern Australia: role of the East Australian Current. Estuar Coast Shelf Sci 72:102-114

> Bowen BW, Bass AL, Soares L, Toonen RJ (2005) Conservation implications of complex population structure: lessons from the loggerhead turtle (Caretta caretta). Mol Ecol 14: 2389-2402

Chaplin JA, Baudains GA, Gill HS, McCulloch R, Potter IC (1998) Are assemblages of black bream (Acanthopagrus butcheri) in different estuaries genetically distinct? Int J Salt Lake Res 6:301-321

Curley BG, Gillings MR (2009) Population connectivity in the temperate damselfish Parma microlepis: analyses of genetic structure across multiple spatial scales. Mar Biol 156:381-393

Dittman A, Quinn T (1996) Homing in pacific salmon: mechanisms and ecological basis. J Exp Biol 199:83-91

Dixson SL, Jones GP, Mundy PL, Planes S, Pratchett MS, Srinivasan M, Sysms C, Thorrold SR (2008) Coral reef fish smell leaves to find island homes. Proc R Soc Lond B 275: 2831-2839

Edgar GJ (2000) Australian marine life: the plants and animals of temperate waters. Reed New Holland, Sydney

Fraser CI, Spencer HG, Waters JM (2009) Glacial oceanographic contrasts explain phylogeography of Australian bull kelp. Mol Ecol 18:2287-2296

> Gerlach G, Atema J, Kingsford MJ, Black KP, Miller-Sims V (2007) Smelling home can prevent dispersal of reef fish larvae. Proc Natl Acad Sci USA 104:858-863

Godfrey JS, Cresswell GR, Golding TJ, Pearce AF (1980) The separation of the East Australian Current. J Phys Oceanogr 10:430-440
Gold JR, Richardson LR, Turner TF (1999) Temporal stability and spatial divergence of mitochondrial DNA haplotype frequencies in red drum (Sciaenops ocellatus) from coastal regions of the western Atlantic Ocean and Gulf of Mexico. Mar Biol 133:593-602

> Griffiths SP (2001) Recruitment and growth of juvenile yellowfin bream, Acanthopagrus australis Günther (Sparidae), in an Australian intermittently open estuary. J Appl Ichthyology 17:240-243

Henry GW (1983) Biology and fisheries of yellowfin bream Acanthopagrus australis (Teleostei: Sparidae) in Tuggerah Lakes, New South Wales. MSc thesis, University of New South Wales, Sydney

Henry GW, Lyle JM (2003) The national recreational and indigenous fishing survey. New South Wales Fisheries Final Report Series, Report No. 48, ISSN 1440-3544

James MK, Armsworth PR, Mason LB, Bode L (2002) The structure of reef fish metapopulations: modelling larval dispersal and retention patterns. Proc R Soc Lond B 269: 2079-2086

Johnson MS, Creagh S, Moran M (1986) Genetic subdivision of stocks of snapper, Chrysophrys unicolor, in Shark Bay, Western Australia. Aust J Mar Freshw Res 37:337-345

Johnson CR, Ling S, Ross J, Shepherd SA, Miller K (2005) Establishment of the long-spined sea urchin (Centrostephanus rodgersii) in Tasmania: first assessment of potential threats to fisheries. Fisheries Research and Development Corporation Final Report 2001/044, University of Tasmania, Hobart

Jones GP, Milicich MJ, Emslie MJ, Lunow C (1999) Selfrecruitment in a coral reef fish population. Nature 402: 802-804

Miller MP (1997) Tools for population genetic analyses (TFPGA) 1.3: a Windows program for the analysis of allozyme and molecular data. Available at www.ccg. unam.mx/ vinuesa/tlem09/docs/TFPGADOC.pdf (computer software distributed by the author)

$>$ Murray-Jones SE, Ayre DJ (1997) High levels of gene flow in the surf bivalve Donax deltoides (Bivalvia: Donacidae) on the east coast of Australia. Mar Biol 128:83-89

Neira FJ, Miskiewicz AG, Trnski T (1998) Larvae of temperate Australian fishes: laboratory guide for larval fish identification. University of Western Australia Press, Melbourne

> Nilsson CS, Cresswell GR (1980) The formation and evolution of East Australian warm-core eddies. Prog Oceanogr 9: 133-183

Pollock BD (1982a) Movements and migrations of yellowfin bream, Acanthopagrus australis (Günther), in Moreton Bay, Queensland as determined by tag recoveries. J Fish Biol 20:245-252

Pollock BR (1982b) Spawning period and growth of yellowfin bream, Acanthopagrus australis (Gunther), in Moreton Bay, Australia. J Fish Biol 21:349-355

> Pollock BR (1984) Relations between migration, reproduction and nutrition in yellowfin bream Acanthopagrus australis. Mar Ecol Prog Ser 19:17-23

Roberts DG, Gray CA, West RJ, Ayre DJ (2009) The evolutionary impacts of hybridization and interspecific gene flow on an obligately estuarine fish. J Evol Biol 22:27-35

> Roberts DG, Gray CA, West RJ, Ayre DJ (2010) Marine genetic swamping: hybrids replace an obligately estuarine fish. Mol Ecol 19:508-520

> Roughan M, Middleton JH (2004) On the East Australian Current: variability, encroachment, and upwelling. J Geophys Res 109:C07003, doi: 10.1029/2003JC001833

Rowland SJ (1984) Hybridization between the estuarine 
fishes yellowfin bream, Acanthopagrus australis (Gunther), and black bream, Acanthopagrus butcheri (Munro) (Pisces, Sparidae). Aust J Mar Freshw Res 35:427-440

Shetty S, Shine R (2002) Philopatry and homing behaviour of sea snakes (Laticauda colubrina) from two adjacent islands in Fiji. Conserv Biol 16:1422-1426

Starr RM, Sala E, Ballesteros E, Zabala M (2007) Spatial dynamics of the Nassau grouper Epinephelus striatus in a Caribbean atoll. Mar Ecol Prog Ser 343:239-249

Thorrold SR, Latkoczy C, Swart PK, Jones CN (2001) Natal homing in a marine fish metapopulation. Science 291: 297-299

van Oosterhout C, Hutchinson WF, Wills DPM, Shipley P (2004) MICRO-CHECKER: software for identifying and correcting genotyping errors in microsatellite data. Mol Ecol Notes 4:535-538

Waters JM, McCulloch GA, Eason JA (2007) Marine biogeographical structure in two highly dispersive gastropods: implications for trans-Tasman dispersal. J Biogeogr 34: 678-687

Editorial responsibility: John Choat,

Townsville, Australia
Watts RJ, Johnson MS (2004) Estuaries, lagoons and enclosed embayments: habitats that enhance population subdivision of inshore fishes. Mar Freshw Res 55:641-651

> Weir BS, Cockerham CC (1984) Estimating F-statistics for the analysis of population structure. Evolution 38: $1358-1370$

West RJ (1993) Estuarine fisheries resources of two south eastern Australian rivers. PhD dissertation, University of New South Wales, Sydney

Wright S (1931) Evolution in Mendelian populations. Genetics 16:97-159

Wright S (1969) Evolution and the genetics of populations, Vol 2. The theory of gene frequencies. University of Chicago Press, Chicago, IL

Yamamoto Y, Hino H, Ueda H (2010) Olfactory imprinting of amino acids in lacustrine sockeye salmon. PLoS ONE 5:e8633, doi: 10.1371/journal.pone.0008633

Yeh FC, Yang R, Boyle T (1999) POPGENE version 1.31: Microsoft Window-based freeware for population genetic analysis. Available at www.ualberta.ca/ fyeh/

Submitted: August 31, 2009; Accepted: May 24, 2010

Proofs received from author(s): July 28, 2010 